\section{IMÁGENES DE UN JUEGO \\ SOCIAL Y SIMBÓLICO. \\ LOS CARNAVALES ROSARINOS \\ ENTRE 1900 Y 1945 \\ DIEGO P. ROLDÁN}

Diego P. Roldán es Profesor de la Facultad de Humanidades de la Universidad Nacional de Rosario e Investigador Asistente del CONICET con sede en el Centro de Estudios Sociales Regionales de esa universidad.

e-mail: diegrol@hotmail.com

\section{Resumen}

Este artículo estudia el desenvolvimiento de los carnavales de Rosario, durante el período 1910-1945. Explora las fórmulas normativas, sus desviaciones y las teatralizaciones lúdicas de la inversión y la afirmación social durante los festejos carnavalescos. El campo de análisis está construido por las relaciones socio-culturales de agentes dominantes y subalternos. Desde una perspectiva relacional, el artículo pretende ofrecer una aproximación a las gramáticas sociales, culturales y políticas que se expresan en las variaciones de estas celebraciones.

\section{Summary}

This article examines the development of Rosario's Carnivals, during the period 1910-1945. It explores the regulations, deviations and staging of social inversion and affirmation. The field of analysis is built by socio-cultural relations shaped by dominant and subordinate agents. From a relational perspective, the article offers an approach to social grammars, cultural and political changes expressed in these celebrations. 